\title{
ANALISIS SITIRAN MAKALAH KONFERENSI PERPUSTAKAAN DIGITAL INDONESIA (KPDI) 1-8
}

\author{
Irdaniajati ${ }^{1 *}$; Wardiyono ${ }^{2 *}$ \\ ${ }^{1}$ Bidang Pengembangan Perpustakaan Sekolah dan Perguruan Tinggi, Perpustakaan Nasional RI \\ 2 Jurusan Ilmu Perpustakaan, Fakultas Teknologi Informasi, Universitas Yarsi \\ *Korespondensi: irdania_2005@yahoo.com, wardiyono@yarsi.ac.id
}

\begin{abstract}
ABSTRAK
Makalah-makalah yang dipaparkan dalam pertemuan tahunan KPDI ke 1-8 adalah tulisan dengan topik seputar perpustakaan digital. Makalah tersebut dibuat oleh Pustakawan, Peneliti, Staf Pusat Informasi dan Dokumentasi yang ikut berpartisipasi. Penelitian ini merupakan penelitian deskriptif untuk melihat pola-pola hubungan antara tulisan selama konferensi dengan pendekatan analisis sitiran. Objek penelitian adalah artikel atau daftar pustaka yang disitir dalam makalah KPDI ke 1-8. Metode pengumpulan data yang digunakan adalah metode dokumentasi. Hasil penelitian menunjukan bahwa jenis literatur artikel adalah yang dominan disitir oleh penulis sebesar 38,35\%. Bahasa yang paling banyak disitir adalah bahasa Inggris dengan jumlah 638 kali. Usia literatur yang disitir 0-10 tahun terakhir mendominasi dalam penulisan makalah KPDI dengan prosentase 70,27\%. Kontribusi institusi tertinggi yaitu Lembaga Ilmu Pengetauan Indonesia (LIPI). Subjek terbanyak yang banyak ditulis pada makalah KPDI 1-8 berkaitan dengan operasional perpustakaan. Peringkat pengarang tertinggi yang disitir atas nama orang adalah Putu Laxman Pendit, sedangkan untuk pengarang atas nama badan/institusi yang sering disitir adalah Perpustakaan Nasional RI. Tingkat kolaborasi penulis dalam makalah KPDI 1-8 terdiri atas sebagian besar pengarang tunggal.
\end{abstract}

Kata kunci: Analisis Sitiran; Makalah KPDI; Perpustakaan Digital.

\section{PENDAHULUAN}

Perkembangan teknologi informasi telah memberikan dampak positif yang sangat besar dalam semua aspek kehidupan manusia, termasuk dunia perpustakaan. Perubahan konsep perpustakaan konvensional menjadi perpustakaan digital, membuat akses informasi perpustakaan secara virtual merupakan salah satu contohnya. Perpustakaan digital merupakan sebuah sistem perpustakaan yang menggunakan teknologi elektronik dalam menyampaikan informasi dari sumber yang dimiliki dan menggabungkan koleksi-koleksi, layanan serta sumber daya manusia untuk mendukung penuh siklus penciptaan, diseminasi, pemanfaatan dan penyimpanan data informasi, serta pengetahuan dalam format digital yang telah dievaluasi, diatur, diarsip dan disimpan, melalui komputer stand alone, intranet, atau internet (Arms, 2001). 
Perpustakaaan Nasional mengadakan Konferensi Perpustakaan Digital Indonesia (KPDI) sebagai fasilitator jejaring perpustakaan digital di Indonesia. Tugas ini menjadi bagian dari salah satu tugas Perpustakaan Nasional sebagai Pembina dari seluruh perpustakaaan di Indonesia. KPDI diharapkan dapat menjadi wadah bagi para penyelenggara perpustakaan dan pustakawan Indonesia untuk saling bertukar pikiran dan pengalaman guna pengembangan jejaring perpustakaan berbasiskan teknologi informasi dan komunikasi. Konferensi ini memaparkan tentang berbagai aspek perpustakaan digital yang dituangkan dalam makalah.

Disetiap penyelenggaraan KPDI, setiap tulisan diharapkan memiliki topik yang berhubungan dengan tema utama konferensi dengan penekanan pada perpustakaan digital namun tidak menutup kemungkinan topik-topik yang masih terkait dengan perpustakaan digital. Sebelum dipresentasikan, tulisan-tulisan ini telah melalui proses seleksi dengan kriteria yang telah ditetapkan oleh panitia. Penulis makalah berasal dari kalangan Pustakawan, Peneliti, dan Staf Pusat Informasi dan Dokumentasi.

Dalam menulis makalah, penulis mensitir sumber-sumber yang dianggap paling sesuai dengan tema tulisannya seperti yang ditulis Djiwandono (2015), sitiran adalah tindakan mengutip pendapat orang lain dari buku atau naskah lain sebagai dukungan terhadap ide yang sedang ditulis. Sitiran juga merupakan rujukan pada teks dan pengakuan informasi dari artikel (Fooladi, 2013). Sophia (2002) menyatakan bahwa sitasi menunjukkan asal-usul atau sumber suatu kutipan, mengutip pernyataan, atau menyalin/mengulang pernyataan seseorang dan mencantumkannya di dalam suatu karya tulis yang dibuat, namun tetap mengindikasikan bahwa kutipan tersebut adalah pernyataan orang lain. Selanjutnya Reitz (2004) menyatakan bahwa sitiran merupakan acuan tertulis pada suatu karya tertentu (buku, artikel, disertasi, laporan, komposisi musik dan lain-lain) yang dihasilkan oleh pengarang, editor, komposer dan lain-lain, yang secara jelas menunjukkan sesuatu dokumen, dimana karya itu diperoleh. Atau dengan kata lain dapat disimpulkan disimpulkan bahwa sitiran adalah informasi literatur yang dijadikan sebagai acuan tertulis dalam rangka membuat sebuah karya tulis.

Analisis sitiran, salah satu kajian informasi terhadap daftar kepustakaan. telah dilakukan pada bagian jurnal karya ilmiah dan buku (Gundry, Senapatiratne \& Trott, 2015). Analisis sitiran menguji frekuensi (keseringan), pola dan grafik sitiran yang terdapat dalam artikel, makalah review, teknik komunikasi, tesis dan buku. Sitiran digunakan dalam berbagai karya ilmiah utuk membangun hubungan dengan peneliti dan karya-karya lainnya, yang membentuk 
salah satu bagian utama dari komunikasi ilmiah dalam sebuah area geografi. Analisis sitiran juga digunakan sebagai sarana evaluasi penelitian yang paling sering digunakan dalam ilmu perpustakaan dan informasi (Sing, Sharma \& Kaur, 2011).

Menurut Parlina, Afandi \& Octavia (2012) analisis sitiran adalah kajian untuk mengetahui keterkaitan dokumen sitiran dengan dokumen yang menyitir. Analisis dapat meliputi berbagai aspek, baik aspek subyek, aspek bahasa, jenis, bentuk dan aspek apa pun yang terkait dengan sitiran. Hasugian (2005) menerangkan bahwa analisis sitiran adalah kajian bibliometrika yang secara khusus mengkaji tentang sitiran yaitu melakukan analisis terhadap daftar pustaka atau bibliografi yang tercantum dalam sebuah dokumen.

Penggunaan dan pemanfaatan analisis sitiran terus berkembang sejak diperkenalkan pertama kali oleh Gross dan Gross pada tahun 1927. Tujuan penggunaan itu antara lain:

1. Untuk menggambarkan pola sitiran dan karakteristik dari literatur yang digunakan dalam suatu kegiatan ilmiah pada bidang atau sub-bidang ilmu tertentu.

2. Untuk mengukur penyebaran hasil penemuan yang dimuat dalam berbagai jenis literatur, seperti misalnya terbitan pemerintah, disertasi, atau terbitan lain yang sejenis.

3. Untuk kajian terhadap pemakai perpustakaan.

4. Untuk menggambarkan pola komunikasi ilmiah.

5. Untuk evaluasi bibliometrik.

6. Sebagai sarana temu kembali informasi.

7. Sebagai salah satu sarana untuk menentukan kebijakan pengembangan koleksi (Rupadha 2011)

Lasa menyatakan (2005) adanya penyitiran karya tulis membawa beberapa manfaat, antara lain: (a) menjunjung etika keilmuan; (b) pengakuan terhadap prestasi seseorang; (c) mengenali metode maupun peralatan; (d) adanya penghormatan terhadap karya orang lain; (e) membantu pembaca dalam penemuan kembali akan sumber informasi; (f) memperoleh latar belakang bacaan; (g) mengoreksi karya karya sendiri atau karya orang lain; (h) memberikan kepuasan; (i) mendukung klaim suatu temuan; (j) membuktikan keaslian data; (k) menyangkal atau membenarkan pemikiran atau gagasan seseorang; dan (l) mendiskusikan gagasan dan penemuan orang lain.

KPDI pertama diselenggarakan pada tanggal 2 Desember 2008 dan diselenggarakan secara berkala setiap tahun (http://kpdi2.pnri.go.id/inex.html). Meski topik perpustakaan digital 
banyak menjadi pembicaraan akhir-akhir ini, tidak banyak penelitian tentang analisis sitiran dari tulisan terkait dengan perpustakaan digital. Akibatnya karakteristik penggunaan literatur dalam penulisan makalah dengan topik perpustakaan digital tidak banyak ditemukan. Penelitan ini diharapkan dapat memberikan gambaran umum terhadap pola dan karekteristik literatur tentang topik perpustakaan digital di Indonesia, khususnya makalah-makalah KPDI 1-8. Penggunaan analisis sitiran diharapkan mampu memberikan masukan untuk melakukan evaluasi terhadap penyelenggaraan KPDI dimasa mendatang.

\section{METODE}

Metode yang digunakan dalam penelitian ini adalah metode deskriptif. Sehingga penelitian ini menekankan pada pengumpulan fakta dan identifikasi data. Populasi dalam penelitian ini adalah makalah KPDI ke 1-8. Untuk penarikan sampel, jumlah sampelnya diambil keseluruhan karena populasi dalam penelitian ini makalahnya berjumlah kurang dari 100. Jumlah makalah seluruhnya sebanyak 92 makalah.

Metode pengumpulan data yang akan digunakan adalah metode dokumentasi, dengan memperoleh data dari daftar pustaka atau sitiran dalam makalah KPDI ke 1-8. Selanjutnya langkah-langkah yang akan dilakukan dalam pengumpulan data adalah sebagai berikut :

a. Mengumpulkan semua makalah dari acara KPDI ke 1-8

b. Memeriksa dan memberi nomor makalah dari semua makalah yang telah dikumpulkan

c. Selain mengumpulkan secara hardcopy juga dilakukan pengumpulan materi softcopy dengan merujuk situs http://perpusnas.go.id/konferensi-perpustakaan-digital/

d. Download daftar pustaka dari setiap makalah KPDI ke 1-8

e. Membuat lembar kerja dalam bentuk tabel dengan menggunakan Microsoft Excel.

Untuk keperluan tersebut dibuat lembar kerja yang memuat 5 kolom meliputi : (1) kolom nomor urut, (2) kolom judul buku/artikel, (3) kolom Pengarang, (4) kolom tahun terbit, (5) kolom jenis literatur (6) bahasa literatur dan lembaga penulis makalah.

Sebelum melakukan analisis, data -data yang telah dikumpulkan, disederhanakan dalam bentuk tabel sehingga mudah dibaca untuk kemudian diinterpretasi. Proses pengolahan data jaringan pengarang dilakukan dengan menggunakan program Pajek untuk menganalisis dan memvisualisasi jaringan. Agar data dapat diproses melalui program Pajek, maka data matriks nama penulis makalah dan literatur yang disitir di tulis dalam berkas berekstensi net (dibaca 
dot net). Rumusan penulisan program analisis network ini merujuk tulisan Mrvar (1998). Metode perhitungan yang digunakan untuk menghitung tingkat kolaborasi antar penulis makalah adalah dengan metode Subramanyam (1983) dengan rumus:

$$
\mathrm{C}=\mathrm{nm} /(\mathrm{nm}+\mathrm{ns})
$$

Dimana:

$\mathrm{C}=$ tingkat kolaborasi penulis salam suatu disiplin ilmu dengan nilai berada pada interval 0 sampai dengan 1 , atau $[0,1]$

$\mathrm{Nm}=$ total hasil penelitian dari peneliti suatu disiplin ilmu pada tahun tertentu yang dilakukan secara berkolaborasi

Ns = total hasil penelitian dari suatu disiplin ilmu pada tahun tertentu yang dilakukan secara individual

Untuk menganalisa subyek yang sering bahas dalam makalah KPDI 1-8, dilakukan dengan cara analisis subyek dokumen dengan menggunakan Dewey Decimal Classification (DDC) edisi 23. Hasil analisis subyek dikelompokkan dalam tabel (digeneralisir sesuai kelas besar DDC) dan dihitung berdasakan masing-masing subyek besarnya.

\section{HASIL DAN PEMBAHASAN}

\subsection{Jumlah Literatur yang Disitir}

Makalah bertopik perpustakaan digital adalah makalah yang pernah dipaparkan dalam pertemuan tahunan KPDI ke 1 - 8. Selama 8 kali KPDI dilaksanakan, jumlah makalah KPDI tampak berbeda setiap tahunnya. Total makalah KPDI ke 1-8 sebanyak 92 judul makalah, dengan rata-rata jumlah makalah setiap KPDI adalah 11 makalah. Dari 92 makalah berhasil diidentifikasi jumlah sitiran adalah 1.056 sitiran.

Ketika menulis karya ilmiah, seorang peneliti harus memahami dokumen yang akan dijadikan rujukan. Oleh karena itu, sebuah dokumen yang akan disitir oleh penulis atau peneliti sebisa mungkin harus relevan dengan topik yang sedang diteliti. Pengambilan keputusan untuk menyitir atau tidak suatu dokumen dilakukan dengan menerapkan beberapa kriteria. Merujuk kepada Wang dan Soergel dalam Dewi (2015), maka penulis bisa memilih kriteria-kriteria penyitiran dokumen: (i) Kesesuaian topik; (ii) Orientasi isi; (iii) Kesamaan disiplin ilmu; (iv) Novelty/kebaruan; (v) Expected Quality: menilai terlebih dahulu keunggulan dan kekurangan dari dokumen yang akan disitir; (vi) Kemutakhiran/Recentcy dokumen (vii) Kendala waktu yang dimiliki penulis; (viii) Kemudahan dalam mendapatkan dokumen; (ix) Syarat khusus 
untuk isi dari dokumen (misalnya bahasa); (x) Authority, dari penulis dokumen rujukan; (xi) Relation/Origin, terkait kedekatan hubungan penulis dengan pengarang/penerbit dokumen.

\subsection{Jenis Literatur yang Disitir}

Berdasarkan tabel 1 dapat diketahui peringkat teratas tentang jenis literatur yang sering disitir oleh penulis makalah KPDI 1-8 adalah artikel. Banyaknya sitiran terhadap artikel dapat saja disebabkan karena artikel merupakan literatur yang lebih update dibandingkan dengan sumber literatur-literatur lainnya. Dalam penyitiran artikel tersebut, penulis makalah menggunakan 2 jenis bentuk artikel yaitu artikel cetak dan artikel online, dimana dalam hal ini penulis mayoritas lebih cenderung menyitir artikel cetak daripada artikel online.

Tabel 1 Jenis Literatur yang Disitir

\begin{tabular}{|c|c|c|c|c|}
\hline Peringkat & \multicolumn{2}{|c|}{ Jenis Literatur } & Frekuensi & $\%$ \\
\hline 1 & Artikel & Tercetak & 246 & 23,30 \\
\hline & & Online & 159 & 15,06 \\
\hline 2 & Buku & Tercetak & 265 & 25,09 \\
\hline & & Online & 16 & 1,52 \\
\hline 3 & \multicolumn{2}{|c|}{ Materi Diklat } & 4 & 0,38 \\
\hline 4 & \multicolumn{2}{|c|}{ Ensiklopedi } & 8 & 0,76 \\
\hline 5 & \multicolumn{2}{|l|}{ Kamus } & 9 & 0,85 \\
\hline 6 & \multicolumn{2}{|c|}{ Situs Internet } & 115 & 10,89 \\
\hline 7 & \multicolumn{2}{|c|}{ Koran online } & 4 & 0,38 \\
\hline 8 & Makalah & Tercetak & 133 & 12,59 \\
\hline & & Online & 41 & 3,88 \\
\hline 9 & \multicolumn{2}{|l|}{ Prosiding } & 4 & 0,38 \\
\hline 10 & \multicolumn{2}{|c|}{ Peraturan/UU, Kepmen, Kepres } & 35 & 3,31 \\
\hline 11 & \multicolumn{2}{|c|}{ Skripsi, Tesis, Disertasi } & 17 & 1,61 \\
\hline
\end{tabular}

\subsection{Bahasa Literatur yang Banyak Disitir}

Berdasarkan hasil penelitian ini, ada 4 (empat) bahasa literatur yang digunakan dalam makalah KPDI ke 1-8 yaitu bahasa Indonesia, bahasa Inggris, bahasa Perancis dan bahasa Belanda, dapat dilihat pada Gambar 1. 
Bibliotech : Jurnal Ilmu Perpustakaan dan Informasi, 3 (1) 2018



Gambar 1 Bahasa Literatur yang banyak Disitir

Penggunaan literatur berbahasa Inggris ini memperlihatkan bahwa mayoritas penulis makalah berkapabilitas dalam hal penggunaan bahasa asing, khususnya untuk bahasa Inggris sehingga memudahkan mereka untuk memahami literatur-literatur yang menggunakan bahasa Inggris, terutama jurnal ilmiah dalam dunia teknologi yang banyak diproduksi oleh penelitipeneliti dari luar.

\subsection{Usia Literatur yang Disitir}

Menyitir suatu literatur memerlukan pertimbangan tentang usia atau tahun terbit. Dalam gambar 2 menunjukkan bahwa usia literatur yang disitir 0-10 tahun terakhir mendominasi dalam penulisan makalah KPDI. Berdasarkan data tersebut, kumulatif prosentase usia literatur yang disitir dalam makalah KPDI 1-8 berada pada usia dibawah 10 tahun dari usia penulisan. Dapat dinyatakan bahwa pada umumnya tahun terbit dari seluruh literatur yang disitir, usianya masih belum mencapai titik keusangan dan informasinya masih tergolong mutakhir.

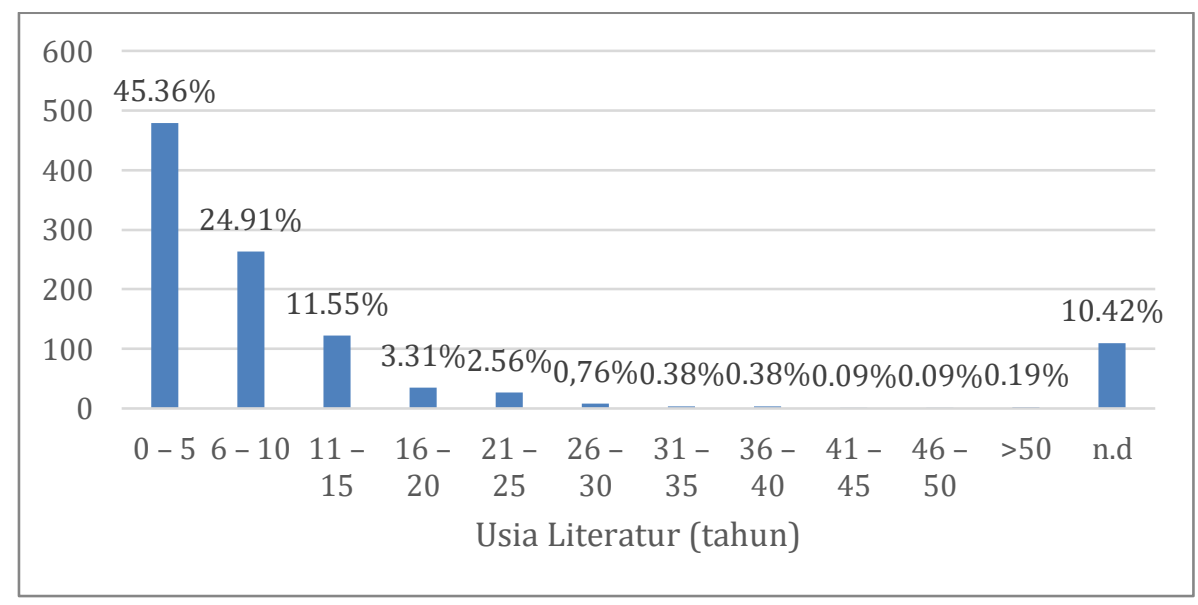

Gambar 2 Prosentasi Usia Literatur 


\subsection{Lembaga Institusi Penulis}

Institusi adalah tempat dimana penulis makalah bekerja. Berdasarkan tabel 2, kontribusi institusi terhadap makalah KPDI 1-8 sebagian besar dari Lembaga Ilmu Pengetahuan Indonesia (LIPI).

Tabel 2 Tiga (3) Peringkat Teratas Lembaga Institusi Penulis

\begin{tabular}{|c|l|c|}
\hline Peringkat & Institusi & $\begin{array}{c}\text { Jumlah Penulis } \\
\text { Makalah }\end{array}$ \\
\hline 1 & Lembaga Ilmu Pengetahuan Indonesia & 26 \\
\hline 2 & Perpustakaan Nasional Republik Indonesia & 10 \\
\hline 3 & UPT. Perpustakaan Universitas Syiah kuala & 7 \\
\hline
\end{tabular}

\subsection{Subyek Makalah KPDI 1-8}

Tabel 3 menunjukkan subyek yang dominan ditulis pada makalah KPDI 1-8 yaitu operasional perpustakaan. Jumlahnya cukup jauh dibandingkan dengan subyek lain yang ditemukan. Diskusi dalam KPDI bisa dinyatakan sebagian besar masih berkutat pada operasional perpustakaan digital. Pemanfaatan dalam bidang lainnya masih kecil nilainya. Pernyataan ini menarik untuk dijadikan topik penelitian lebih lanjut terkait topik pemanfaatan bidang lain dari perpustakaan digital yang masih sedikit.

Tabel 3 Peringkat Subyek yang paling sering ditulis

\begin{tabular}{|c|l|c|}
\hline Peringkat & Subyek & Jumlah \\
\hline 1 & Operasional Perpustakaan & 124 \\
\hline 2 & Program Komputer, program, data & 27 \\
\hline 3 & Ilmu Komputer & 22 \\
\hline 4 & $\begin{array}{l}\text { Hubungan Perpustakaan, Arsip dan } \\
\text { Informasi }\end{array}$ & 22 \\
\hline
\end{tabular}

\subsection{Pola Kepengarangan dalam Makalah KPDI ke 1-8}

Analisis sitiran bisa digunakan untuk mengukur pengaruh intelektual keilmuan dari pengarang yang disitir, untuk mengetahui karakteristik komunikasi ilmu pengetahuan dan banyak aspek kualitatif dari penelitian dan publikasi (Junandi dan Zulaikha, 2010). Dalam

peringkat pengarang yang disitir, pengarang dibuat dua kelompok, yaitu pengarang atas nama orang dan pengarang atas nama badan atau institusi. Berdasarkan tabel 4 dan 5 menunjukan bahwa untuk bidang perpustakaan digital, penulis makalah KPDI 1-8 lebih merujuk pada karya 
Putu Laxman Pendit. Sedangkan Perpustakaan Nasional RI dijadikan referensi tentang undangundang tentang perpustakaan.

Tabel 4 Pengarang atas nama orangi yang sering disitir

\begin{tabular}{|l|l|c|}
\hline No & \multicolumn{1}{|c|}{ Pengarang } & Jumlah \\
\hline 1. & Putu Laxman Pendit & 19 \\
\hline 2 & Sulistyo Basuki & 11 \\
\hline 3 & Lukman & 10 \\
\hline 4 & Rizal Fathoni Aji & 10 \\
\hline
\end{tabular}

Tabel 5 Pengarang atas nama badan/institusi yang sering disitir

\begin{tabular}{|l|l|c|}
\hline No & \multicolumn{1}{|c|}{ Pengarang } & Jumlah \\
\hline 1. & Perpustakaan Nasional & 43 \\
\hline 2 & $\begin{array}{l}\text { National Information Standards } \\
\text { Organization }\end{array}$ & 19 \\
\hline 3 & Kementerian Hukum \& HAM RI & 11 \\
\hline
\end{tabular}

Kolaborasi adalah kerjasama antar lebih dari satu orang pengarang, atau dengan kata lain dalam proses penulisan artikel memerlukan bantuan orang lain. Berdasarkan metode perhitungan Subramanyam (lihat tabel 6) maka didapatkan nilai kolaborasi penulis makalah KPDI 1-8 rendah. Hal ini terbukti dengan melihat gambar 3 yaitu jaringan pola kepengarangan yang merupakan visualiasi dari analisis data dengan aplikasi Pajek. Visualisasi pada gambar 3 secara umum, menunjukkan pola pengarang yang tersebar. Tingkat kolaborasi pengarang makalah yang paling tinggi dalam acara Konferensi Perpustakaan Digital Indonesia (KPDI) 1-8 adalah Harini Yaniar dan Ekawati Marlina yang memiliki kekuatan 4 titik. Sedangkan untuk nama pengarang atas nama orang yang banyak disitir yaitu Putu Laxman Pendit yang memiliki kekuatan 19 titik dan untuk pengarang atas nama badan atau institusi yaitu Perpustakaan Nasional RI yang memiliki kekuatan 19 titik.

Tabel 6 Tingkat Kolaborasi Pengarang

\begin{tabular}{|c|c|c|c|}
\hline KPDI & Penulis Tunggal (ns) & Kolaborasi (nm) & $\begin{array}{c}\text { Tingkat Kolaborasi } \\
(\mathrm{nm} /(\mathrm{ns}+\mathrm{nm})\end{array}$ \\
\hline 1 & 3 & 0 & 0 \\
\hline 2 & 9 & 0 & 0 \\
\hline 3 & 7 & 0 & 0 \\
\hline 4 & 10 & 2 & 0,167 \\
\hline 5 & 7 & 5 & 0,416 \\
\hline 6 & 9 & 6 & 0,4 \\
\hline 7 & 13 & 4 & 0,235 \\
\hline 8 & 9 & 7 & 0,438 \\
\hline TOTAL & 67 & 24 & 0,264 \\
\hline
\end{tabular}




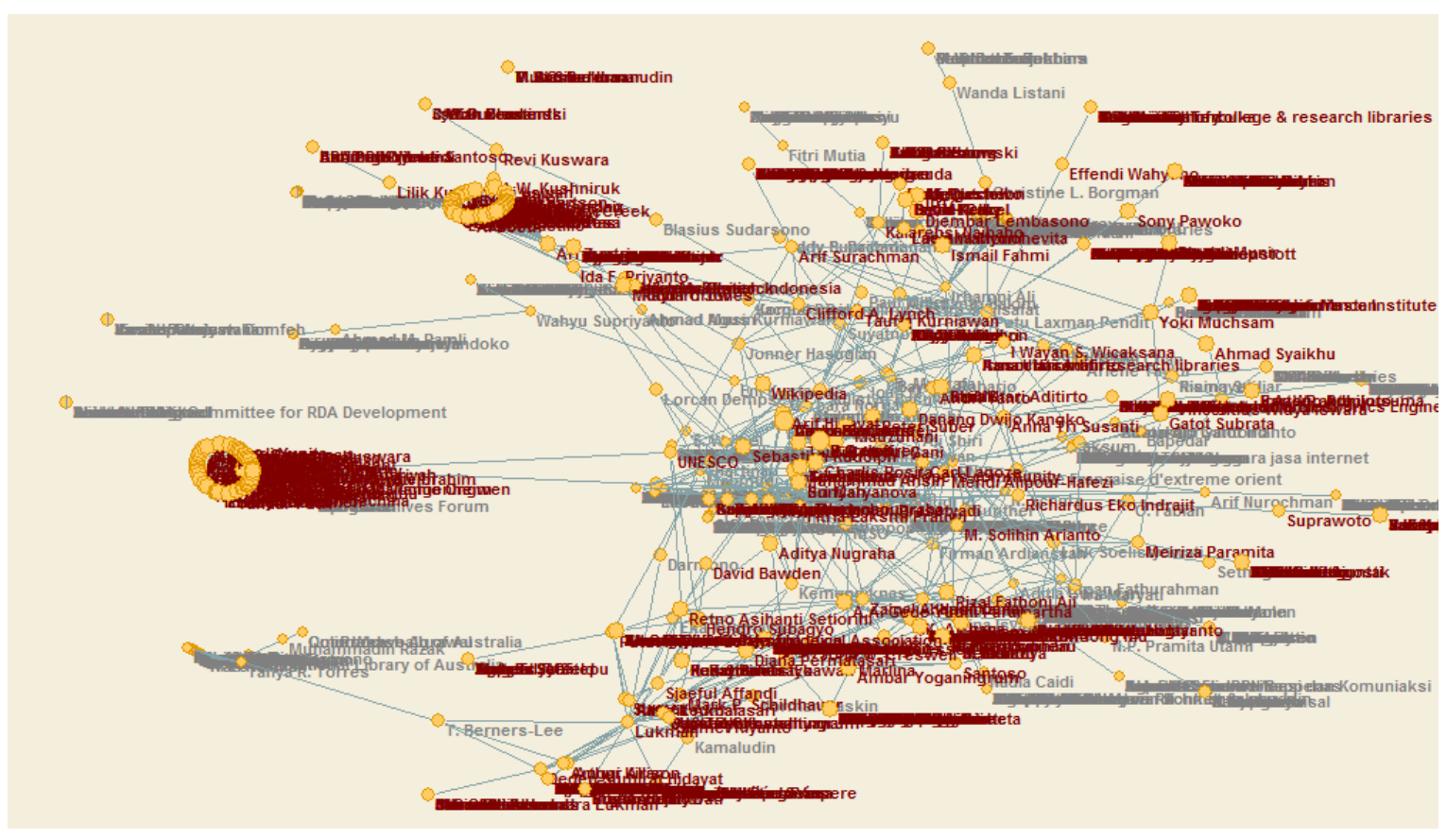

Gambar 3 Pola jaringan pengarang pada makalah KPDI 1-8

\section{KESIMPULAN}

Hasil penelitian sedikit banyak menunjukkan peta kondisi umum perpustakaan digital di Indonesia. Penulis makalah KPDI 1-8 lebih dominan menggunakan artikel sebagai sumber literature yang disitir. Hal ini sesuai dengan kecepatan perkembangan teknologi yang tergambarkan dalam artikel jurnal dibandingkan buku teks. Literatur berbahasa Inggris adalah literatur yang paling banyak dijadikan rujukan, yakni sebanyak 60,42\%. Sedangkan usia literatur yang paling banyak dirujuk penulis makalah tergolong mutakhir dengan usia literatur 0-5 tahun. Lembaga Ilmu Pengetahuan Indonesia (LIPI) merupakan institusi tertinggi dalam menulis makalah KPDI 1-8. LIPI dalam hal ini dapat dianggap sebagai lembaga yang banyak melakukan kajian dan penelitian untuk topik perpustakaan digital. Subyek yang paling sering ditulis dalam makalah KPDI 1-8 masih berkutat pada topik operasional perpustakaan. Setidaknya hal ini menggambarkan kondisi perpustakaan digital di Indoneisa yang masih berkutat dalam masalah operasional dibandingkan dengan pemanfaatan dan pelayanan maupun aspek teknologi perpustakaan digital yang berbasis TIK. Untuk bidang perpustakaan digital, penulis makalah KPDI 1-8 lebih merujuk pada karya Putu Laxman Pendit. Sedangkan Perpustakaan Nasional RI dijadikan referensi tentang Undang-Undang Perpustakaan. 
Bibliotech : Jurnal Ilmu Perpustakaan dan Informasi, 3 (1) 2018

Rendahnya tingkat kolaborasi antar penulis makalah KPDI 1-8 yang dihitung dengan metode Subramanyam juga terbukti dengan melihat visualisasi gambar jaringan pola kepengarangan yang menunjukkan kecenderungan untuk bekerja sendiri-sendiri. Hal ini sebenarnya bertentangan dengan dengan konsep perpustakaan digital yang akan lebih bermanfaat dalam pola kerjasama antar perpustakaan dibandingkan perpustakaan digital yang mandiri.

Pihak penyelenggara KPDI perlu melakukan selektif lebih ketat terhadap subyek-subyek makalah atau topik yang diterima dalam KPDI untuk mampu mendorong perkembangan perpustakaan digital di Indonesia. KPDI dapat menjadi wadah kolaborasi dan sarana komunikasi para ahli perpustakaan digital ditingkat nasional, karena semakin sering penulis berkolaborasi maka kualitas dan kuantitas makalah yang dihasilkan juga akan semakin bermutu.

\section{DAFTAR PUSTAKA}

Arms, W,Y. (2001). Digital Libraries, diakses 15 Februari 2016 http://eresources.perpusnas.go.id:2060/lib/perpusnas/reader.action?docID=2001012\&ppg=13

Dewi, W.S. (2015) Analisis Sitiran Terhadap Tesis Mahasiswa Magister Sains Manajemen Tahun 2010 sampai dengan 2013 dan ketersediaan Literatur di Ruang Baca Fakultas Ekonomi dan Bisnis Universitas Airlangga, diakses 20 Mei 2016, http://journal.unair.ac.id/download-fullpapers-ln49950c4760full.pdf

Djiwandono, P.I. (2015). Meneliti itu tidak sulit : metodologi penelitian sosial dan pendidikan $\begin{array}{lllll}\text { bahasa, } & \text { diakses } & 27 & \text { April }\end{array}$ https://books.google.co.id/books?id=wHumCQAAQBAJ\&pg=PA34\&lpg=PA34\&dq=sit asi + adalah\&source=bl\&ots=BZrRLjLSgn\&sig=ZsoMgnOnlFhOYqZ33liR5_54Vvo\&hl= id\&sa=X\&ved=0ahUKEwjGmYLd18bMAhUUUY4KHT1rDIw4KBDoAQhKMAg\#v=o nepage $\& \mathrm{q}=$ sitasi $\% 20$ adalah $\& \mathrm{f}=$ fals

Fooladi, M. (2013). “Does Criticisms Overcome the Praises of Journal Impact Factor?”, Asian Social Science, hlm. 176-182. Diakses 29 April 2016, http://dx.doi.org/10.5539/ass.v9n5p176

Gundry, J., Senapatiratne, T. \& Trott, G. (2015) "Citation Analysis and Its Potential In Theological Libraries", Theological Librarianship, hlm. 16-22, diakses 15 Februari 2016, 
Bibliotech : Jurnal Ilmu Perpustakaan dan Informasi, 3 (1) 2018

http://web.a.ebscohost.com/ehost/pdfviewer/pdfviewer?sid=24ac9b8c-391e-4650-bbe7995705 c9815a\%40sessionmgr4002\&vid $=0 \&$ hid $=4109$

Hasugian, J. (2005). "Analisis Sitiran terhadap Disertasi Program Doktor (S-3) Ilmu Kedokteran Sekolah Pascasarjana Universitas Sumatera Utara", Pustaha : Jurnal Studi Perpustakaan dan Informasi, Vol.1, No.2, diakses 15 Juni 2016, https://www.google.com/url?q= http://puslit2.petra.ac.id/ejournal/index.php/pus/article/download/17246/17198\&sa=U\&v ed=0ahUKEwi4prr3oYPRAhUs6oMKHbMsDdwQFggWMAc\&client=internaludscse\&usg=AFQjCNFfBLUVvReDcJ6D7AbE2qkinn9INA

Junandi, S., Zulaikha, Sri R. (2010) “Analisis sitiran artikel jurnal luar negeri pada laporan penelitian di Lembaga Penelitian dan Pengabdian kepada Masyarakat UGM yang dibiayai Badan Litbang Pertanian Departemen Pertanian Tahun 2007," Berkala Ilmu Perpustakaan dan Informasi, hlm. 14-22, diakses 22 Februari 2016, http://webcache.googleusercontent.com/search?q= cache:f_p8_Ho50VMJ:jurnal.ugm.ac.id/bip/article/download/9127/6828+\&cd=4\&hl=id $\& \mathrm{ct}=\mathrm{clnk} \& \mathrm{gl}=\mathrm{id}$

Lasa, HS (2005). Manajemen perpustakaan, Gama Media, Yogyakarta.

Mrvar, A. (1998). Pajek, diakses 4 Mei 2016 http://pajek.imfm.si/

Parlina, A, Sjaeful, A \& Octavia, R. (2012) “Analisis Sitiran Jurnal Kedokteran Perguruan Tinggi (Trisakti, Universitas Maranatha, UKI Atmajaya)", BACA : Jurnal Dokumentasi dan Informasi, hlm. 1-8, diakses 4 Mei 2016, http://www.pdii.lipi.go.id/jurnal/index.php/ baca/article/viewFile/103/100

Reitz, J.M. (2004). Dictionary library and information science, diakses 29 April 2016, http://www.abc-clio.com/ODLIS/odlis_c.aspx

Rupadha, I.K. (2011). Memahami karakteristik kebutuhan informasi peneliti dengan metode $\begin{array}{lllll}\text { analisis } & \text { sitasi, } & \text { diakses } & \text { Maret }\end{array}$ http://www.academia.edu/7612113/MEMAHAMI_ KARAKTERISTIK_KEBUTUHAN_INFORMASI_PENELITI_DENGAN_METODE_ ANALISIS_SITASI

Sing, N.K., Sharma, J., \& Kaur, N. (2011) Citation analysis of journal of documentation, diakses 
Bibliotech : Jurnal Ilmu Perpustakaan dan Informasi, 3 (1) 2018

http://n5bn6xp5c.search.serialssolutions.com/?ctx_ver=Z39.88-

$2004 \& c t x \_$enc $=$info $\% 3$ Aofi $\% 2$ Fenc $\% 3$ AUTF-

8\&rfr_id=info:sid/summon.serialssolutions.com\&rft_val_fmt=info:ofi/fmt:kev:mtx:journ al\&rft.genre $=$ article\&rft.atitle $=$ Citation + Analysis + of + Journal + of + Documentation\&rft.jtit le $=$ Webology\&rft.au=Neeraj + Kumar + Singh\&rft.au $=$ Jyoti + Sharma\&rft.au=Navneet + Kau r\&rft.date $=2011-06-$

01\&rft.pub=Dr. + Alireza+Noruzi $\% 2 \mathrm{C}+$ University + of + Tehran $\% 2 \mathrm{C}+$ Department + of + Libr ary+and+Information+Science\&rft.eissn=1735-

188X\&rft.volume=8\&rft.issue $=1 \&$ rft.spage=1\&rft.externalDocID=2454341381\&paramd $\mathrm{ict}=\mathrm{id}$

Sophia, S. (2002). Petunjuk Sitasi serta Cantuman Daftar Pustaka Online. Seri Pengembangan Perpustakaan Pertanian No. 25, hlm. 12, Pusat Perpustakaan dan Penyebaran Teknologi Pertanian, Departemen Pertanian, Bogor

Subramanyam, K. (1983). "Bibliometric Studies of Research Collaboration : A Review", Journal of Information Sciences, 6: 33-38 
Bibliotech : Jurnal Ilmu Perpustakaan dan Informasi, 3 (1) 2018 